\title{
Significance of Intratumoral Fibrosis in Clear Cell Renal Cell Carcinoma
}

Jae Won Joung · Hoon Kyu Oh

Sun Jae Lee · Young Ah Kim

Hyun Jin Jung ${ }^{1}$

Departments of Pathology and ${ }^{1}$ Urology, Catholic University of Daegu School of Medicine, Daegu, Korea

Received: April 23, 2018

Revised: July 16, 2018

Accepted: July 20, 2018

Corresponding Author

Hoon Kyu Oh, MD

Department of Pathology, Catholic University of

Daegu School of Medicine, 33 Duryugongwon-ro

17-gil, Nam-gu, Daegu 42472, Korea

Tel: +82-53-650-4156

Fax: $+82-53-650-3456$

E-mail: ap510@cu.ac.kr
Background: Intratumoral fibrosis (ITF) is a frequent histologic finding in solid organ tumors. Renal cell carcinoma (RCC) is a highly vascularized tumor with different shapes and degrees of ITF and inflammation. ITF is a poor prognostic factor, especially in breast cancer, and is related to intratumoral necrosis (ITN) and intratumoral inflammation (ITI). However, the significance of ITF in RCC has not been fully studied. In this study, we evaluate the relationships between ITF and other clinicopathologic parameters associated with RCC prognosis. Methods: ITF was evaluated in 204 clear cell renal cell carcinoma (CCRCC) specimens according to presence and grade of fibrosis, degree of ITI, and presence of ITN. Lysyl oxidase (LOX) expression in tumor cells was also evaluated with clinicopathologic parameters. Results: Among 204 CCRCC cases, 167 (81.7\%) showed ITF, 71 (34.8\%) showed ITI, 35 (17.2\%) showed ITN, and 111 (54.4\%) showed LOX expression. ITF correlated with Fuhrman nuclear grade $(p=.046)$, lymphovascular invasion $(L V I)(p=.027)$, and ITN $(p=$ .036). Patients with ITF had a poor five-year overall survival rate $(p=.104)$. Conclusions: ITF is related to other poor prognostic factors in CCRCC, such as Fuhrman nuclear grade, ITN, and LVI, but ITF itself had no significant correlation with prognosis of CCRCC.

Key Words: Carcinoma, renal cell; Fibrosis; Inflammation; Protein-lysine 6-oxidase
Renal cell carcinoma (RCC) is a common tumor and is one of the main causes of death by cancer in Western countries. ${ }^{1}$ In Korea, the number of patients diagnosed with RCC has also been increasing recently. ${ }^{2}$ Clear cell renal cell carcinoma (CCRCC) is the most common variant of RCC and represents an aggressive histologic subtype. ${ }^{3}$ CCRCC is a good example of a heterogeneous tumor with different clones in different areas of the same tumor at the genetic level. ${ }^{4,5}$ This may be why it has been difficult to develop targeted or personalized therapies for RCC. ${ }^{6}$ RCC is also resistant to chemotherapy and radiotherapy. The recently increased survival rate of RCC is probably due to early diagnosis and improved surgical techniques. ${ }^{?}$

Metastases are involved in more than $90 \%$ of patients who die from cancer. Many studies have shown that microenvironment and extracellular matrix (ECM) remodeling have crucial roles in accelerating tumor proliferation and metastasis. ${ }^{8-11}$ Lysyl oxidase (LOX) is a copper enzyme with important functions in remodeling of the ECM. ${ }^{12}$ LOX oxidizes the lysine residues of structures that compose the ECM, thereby catalyzing the crosslinks of collagen and elastin fibers to form a mature structure. ${ }^{13,14}$

Intratumoral fibrosis (ITF) and intratumoral inflammation (ITI) are frequent histologic findings in solid organ tumors. Many studies have shown that ITF is a poor prognostic factor, especially in breast cancer, and is related to intratumoral necrosis (ITN) and inflammation. ${ }^{15,16}$ RCC is also a highly vascularized tumor with different shapes and degrees of ITF and ITI. As far as we know, there are nearly no studies of the significance of ITF in RCC.

The goal of our study is to determine the relationships between ITF, ITI, LOX expression, and other prognostic factors of RCC. If ITF, ITI, or LOX is related to poor prognosis of RCC, these findings could be used to identify potential targets for personalized therapies.

\section{MATERIALS AND METHODS}

\section{Patients and materials}

This study was performed on 224 RCC samples diagnosed from 2003 to 2015 at Daegu Catholic University Medical Center. The specimens included 163 total nephrectomies and 61 partial nephrectomies. Follow-up data were started at the time of diagnosis until August 31, 2016. The average follow-up period was 66.3 months, excluding patients lost to follow-up. Two pathologists (H.K. Oh and J.W. Joung) reviewed all slides to evaluate the diagnosis, histologic type, Fuhrman nuclear grade, tumor 
diameter, lymphovascular invasion (LVI), ITF, ITI, and ITN. This study was approved by the Institutional Review Board of Daegu Catholic University Medical Center (CR-18-009-RES001-R) and performed in accordance with the Helsinki declaration. Because this is a retrospective study, informed consent was waived. All patient information was anonymized prior to analysis.

\section{Tissue microarray and immunohistochemistry}

Tissue microarrays that contained representative tumor cores ( $2 \mathrm{~mm}$ in diameter) were used to evaluate LOX expression. Immu- nohistochemistry was performed using polyclonal rabbit LOX antibody (dilution 1:500, Novus Biologicals, Littleton, CO, USA) in the Leica Bond-Max automated immunostainer (Leica Biosystems, Wetzlar, Germany).

\section{Grading of intratumoral fibrosis, intratumoral inflammation,} and LOX expression

ITF is composed of fibroblasts admixed with various volumes of collagen surrounded by tumor cells and located within the tumor boundary. Like many studies in breast cancer, ITF is defined when
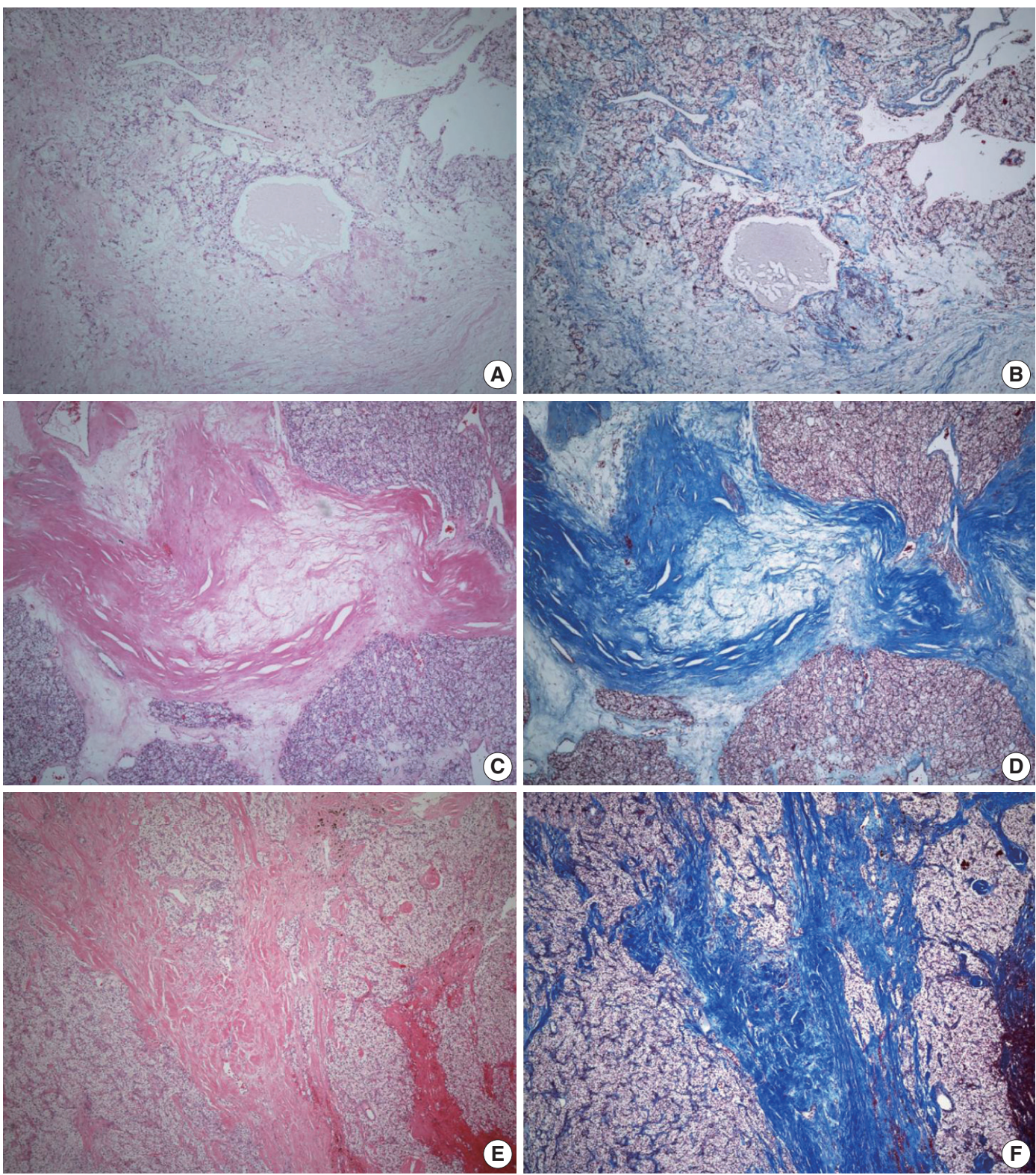

Fig. 1. Intratumoral fibrosis (ITF). Hematoxylin and eosin staining is compared with trichrome staining. (A, B) Grade 1 ITF mainly composed of loose connective tissue. (C, D) Grade 2 ITF composed of collagen fibers and loose connective tissue. (E, F) Grade 3 ITF mainly composed of sclerotic collagen fibers. 
the size is more than $0.1 \mathrm{~cm} .{ }^{15,16}$ In this study, ITF was classified into grades 0 to 3. Grade 0 ITF was defined as no fibrosis within tumor. Grade 1 ITF was mainly composed of loose connective tissue, grade 2 ITF was composed of collagen fibers and loose connective tissue, and grade 3 ITF was mainly composed of thick sclerotic collagen fibers (Fig. 1).

To investigate the relationship between ITF and ITI, ITI was graded from 0 to 3 according to the amount of inflammatory cells within the tumor boundary. Grade 0 ITI had no inflam- matory cell infiltration, while grade 1 ITI had a few scattered inflammatory cells. Grade 2 ITI was characterized by focal aggregation of inflammatory cells, and grade 3 ITI was defined as diffuse or nodular aggregation of inflammatory cells (Fig. 2). ITF grade 0 was classified as negative, and grades 1,2 , and 3 were classified as positive. ITI of 0 or 1 was classified as negative, and ITI grade 2 or 3 was classified as positive.

LOX expression level was graded as 0 to 3 according to the degree of intensity and proportion of stained tumor cells: LOX
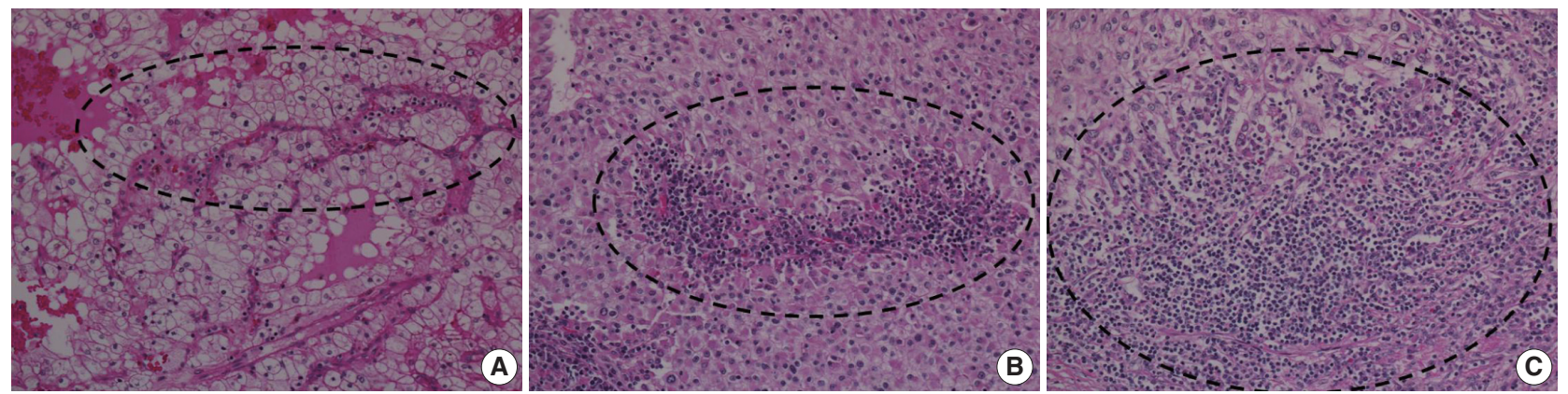

Fig. 2. Intratumoral inflammation (ITI). (A) Grade 1 ITI with scattered inflammatory cells. (B) Grade 2 ITI with focal aggregation of inflammatory cells. (C) Grade 3 ITI with diffuse or nodular aggregation of inflammatory cells.
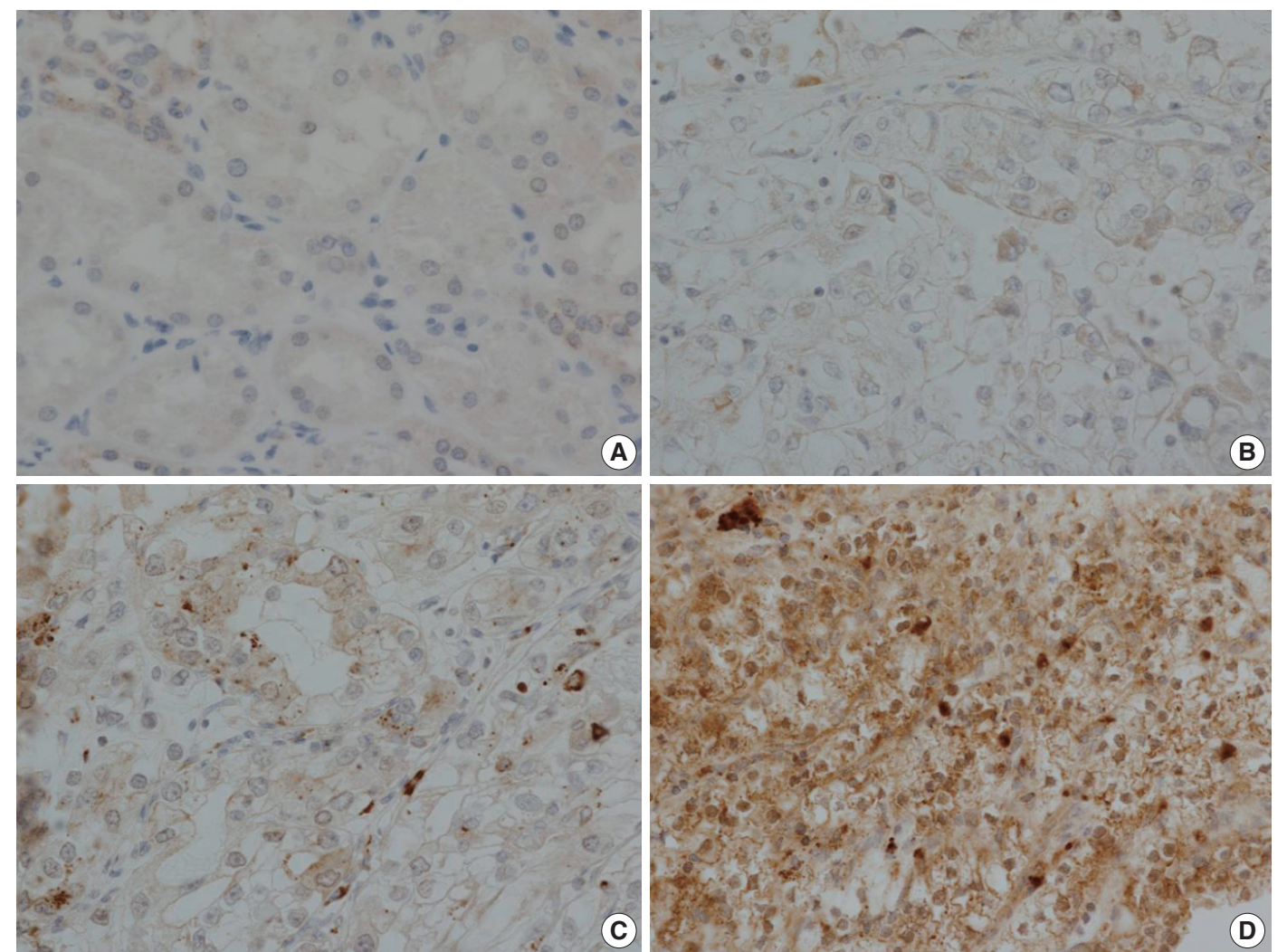

Fig. 3. Immunohistochemical staining of lysyl oxidase (LOX). (A) Control staining of normal kidney. Tubular cells show no reactivity. (B) LOX expression 1, with focal and weak staining in tumor cell cytoplasm. (C) LOX expression 2, with moderate cytoplasmic staining in nearly $50 \%$ of tumor cells. (D) LOX expression 3, with strong and diffuse staining of tumor cell cytoplasm. 
expression is scored as 0 (no staining), 1 (minimal intensity, $<10 \%$ of cells), 2 (moderate intensity, $10 \%-49 \%$ of cells), or 3 (strong intensity, $\geq 50 \%$ of cells). LOX expression was then classified as negative ( 0 and 1 ) or positive ( 2 and 3 ). Every tissue microarray contained normal kidney as a control group. In normal kidneys, tubular cells show no reactivity to LOX (Fig. 3).

\section{Statistical analysis}

All statistical analyses were performed using SPSS software program ver. 19.0 for Windows (SPSS Inc., Chicago, IL, USA). The relationships between ITF, ITI, LOX expression, and clinicopathologic parameters were analyzed using the chi-square test. The 5-year overall survival rate according to presence of ITF was analyzed using the Kaplan-Meier method. The clinicopathologic parameters evaluated were patient age, sex, histologic type, Fuhrman nuclear grade, tumor size, pathologic staging, LVI, and ITN.

\section{RESULTS}

\section{Clinicopathologic characteristics of patients}

In 224 cases of RCC, the three most common tumor types were CCRCC (204 cases), papillary RCC (11 cases), and chromophobe RCC (5 cases). Other types include mucinous RCC (one case), mucinous tubular and spindle-cell carcinoma (one case), oncocytoma (one case), and unclassified RCC (one case). CCRCC cases represented $91.1 \%$ of the total RCC cases (204/224).

Of the 204 patients with CCRCC, 139 (68.1\%) were male and $65(31.9 \%)$ were female. The average age (mean \pm standard deviation $[\mathrm{SD}]$ ) at diagnosis was $59.7 \pm 11.8$ years and ranged between 27 and 87 years. Follow-up data were obtained from 191 patients (93.6\%) with average follow-up period of 50.4 months. Based on the follow-up data available on patients, 11 patients $(5.8 \%)$ died of disease, and 25 patients (13.1\%) had metastasis to other organs.

Average tumor diameter (mean \pm SD) was $4.48 \pm 3.01 \mathrm{~cm}$ (range 0.5 to $19 \mathrm{~cm}$ ). Fuhrman nuclear grade distribution was 12 G1 (5.9\%), 118 G2 (57.8\%), 55 G3 (27.0\%), and 19 G4 (9.3\%). A total of 130 cases $(63.7 \%)$ were low grade (grade 1 and 2), and 74 cases (36.3\%) were high grade (grade 3 and 4). There were 154 cases of pT1 (75.5\%), 19 cases of pT2 (9.3\%), 30 cases of pT3 (14.7\%), and one case of pT4 (0.5\%). A total of 173 cases $(84.8 \%$ ) were low stage (stages 1 and 2), and 31 cases (15.2\%) were high stage (stages 3 and 4 ). When performing statistical analysis, Fuhrman nuclear grade and pathologic T stage were divided into low (nuclear grades 1 and 2 or T stages 1 and 2) and high (nuclear grades 3 and 4 or T stages 3 and 4 ) groups. The clinicopathologic characteristics are listed in Table 1.

\section{Associations between ITF and clinicopathologic characteristics}

ITF was found in 167 cases $(81.7 \%)$, indicating that ITF is a relatively common finding in CCRCC. Clinicopathologic parameters that are strongly associated with ITF are Fuhrman nuclear

Table 1. Clinicopathologic characteristics of patients

\begin{tabular}{|c|c|}
\hline Clinicopathological parameter & No. (\%) \\
\hline \multicolumn{2}{|l|}{ Age (yr) } \\
\hline Mean $\pm S D$ & $59.7 \pm 11.8$ \\
\hline Range & $27-87$ \\
\hline \multicolumn{2}{|l|}{ Tumor size (cm) } \\
\hline Average \pm SD & $4.48 \pm 3.01$ \\
\hline Range & 0.5-19 \\
\hline \multicolumn{2}{|l|}{ Sex } \\
\hline Male & $139(68.1)$ \\
\hline Female & 65 (31.9) \\
\hline \multicolumn{2}{|l|}{ Fuhrman nuclear grade } \\
\hline 1 & $12(5.9)$ \\
\hline 2 & 118 (57.8) \\
\hline 3 & $55(27.0)$ \\
\hline 4 & $19(9.3)$ \\
\hline \multicolumn{2}{|l|}{ Pathologic stage } \\
\hline 1 & $154(75.5)$ \\
\hline 2 & $19(9.3)$ \\
\hline 3 & $30(14.7)$ \\
\hline 4 & $1(0.5)$ \\
\hline \multicolumn{2}{|l|}{ Lymphovascular invasion } \\
\hline Absent & $175(85.8)$ \\
\hline Present & $29(14.2)$ \\
\hline \multicolumn{2}{|l|}{ Tumor necrosis } \\
\hline Absent & $169(82.8)$ \\
\hline Present & $35(17.2)$ \\
\hline \multicolumn{2}{|l|}{ Intratumoral inflammation } \\
\hline 0 & $25(12.3)$ \\
\hline 1 & $108(52.9)$ \\
\hline 2 & $59(28.9)$ \\
\hline 3 & $12(5.9)$ \\
\hline \multicolumn{2}{|l|}{ Intratumoral fibrosis } \\
\hline 0 & $37(18.1)$ \\
\hline 1 & $59(28.9)$ \\
\hline 2 & $77(37.7)$ \\
\hline 3 & $31(15.2)$ \\
\hline \multicolumn{2}{|l|}{ LOX } \\
\hline 0 & $11(5.4)$ \\
\hline 1 & $82(40.2)$ \\
\hline 2 & $82(40.2)$ \\
\hline 3 & $29(14.2)$ \\
\hline
\end{tabular}

SD, standard deviation; LOX, lysyl oxidase. 
grade $(\mathrm{p}=.003), \mathrm{LVI}(\mathrm{p}=.027)$, and ITN $(\mathrm{p}=.036)$ according to presence (grades 1, 2 and 3) and absence (grade 0) of ITF. LOX expression status was not statistically associated with ITF (Table 2).

\section{Associations between ITI and clinicopathologic characteristics}

ITI was found in $71(34.8 \%)$ cases. Clinicopathologic parameters that are strongly associated with ITI are tumor size ( $\mathrm{p}<$ .001), Fuhrman nuclear grade ( $\mathrm{p}<.001)$, pathologic stage $(\mathrm{p}=$ $.004)$, LVI ( $\mathrm{p}<.001)$, and ITN ( $\mathrm{p}<.001)$. The LOX expression status was not statistically associated with ITI (Table 3).

\section{Associations between LOX expression and clinicopathologic characteristics}

LOX expression was found in 111 cases (54.4\%). No clinicopathologic parameters evaluated were statistically associated with LOX expression (Table 4).

Table 2. Associations of intratumoral fibrosis with clinicopathologic characteristics

\begin{tabular}{|c|c|c|c|}
\hline \multirow{2}{*}{$\begin{array}{l}\text { Clinicopathological } \\
\text { parameter }\end{array}$} & \multicolumn{2}{|c|}{ Intratumoral fibrosis } & \multirow{2}{*}{$p$-value } \\
\hline & Absent & Present & \\
\hline \multicolumn{4}{|l|}{ Age (yr) } \\
\hline$<60$ & $21(20.8)$ & 80 (79.2) & .330 \\
\hline$\geq 60$ & $16(15.5)$ & $87(84.5)$ & \\
\hline \multicolumn{4}{|l|}{ Sex } \\
\hline Male & $26(18.7)$ & $113(81.3)$ & .758 \\
\hline Female & $11(16.9)$ & $54(83.1)$ & \\
\hline \multicolumn{4}{|l|}{ Tumor size $(\mathrm{cm})$} \\
\hline$\leq 7$ & $34(20.2)$ & $134(79.8)$ & .093 \\
\hline$>7$ & $3(8.3)$ & $33(91.7)$ & \\
\hline \multicolumn{4}{|l|}{ Fuhrman nuclear grade } \\
\hline Low (grade 1 and 2) & $31(23.8)$ & 99 (76.2) & $.003^{* *}$ \\
\hline High (grade 3 and 4) & $6(8.1)$ & $68(91.9)$ & \\
\hline \multicolumn{4}{|l|}{ Pathologic stage } \\
\hline Low (stage 1 and 2) & $33(19.1)$ & $140(80.9)$ & .295 \\
\hline High (stage 3 and 4) & $4(12.9)$ & $27(87.1)$ & \\
\hline \multicolumn{4}{|l|}{ Lymphovascular invasion } \\
\hline Absent & $36(20.6)$ & $139(79.4)$ & $.027^{*}$ \\
\hline Present & $1(3.4)$ & $28(96.6)$ & \\
\hline \multicolumn{4}{|l|}{ Tumor necrosis } \\
\hline Absent & $35(20.7)$ & $134(79.3)$ & $.036^{*}$ \\
\hline Present & $2(5.7)$ & $33(94.3)$ & \\
\hline \multicolumn{4}{|l|}{ Intratumoral inflammation } \\
\hline Absent & $25(18.8)$ & $108(81.2)$ & .738 \\
\hline Present & $12(16.9)$ & $59(83.1)$ & \\
\hline \multicolumn{4}{|l|}{ LOX expression } \\
\hline Absent & $16(17.2)$ & 77 (82.8) & .752 \\
\hline Present & $21(18.9)$ & $90(81.1)$ & \\
\hline
\end{tabular}

Values are presented as number (\%).

LOX, lysyl oxidase.

${ }^{*} \mathrm{p}<.05,{ }^{* *} \mathrm{p}<.01$.

\section{Associations between ITF and clinicopathologic characteristics}

ITF size was on average $0.56 \mathrm{~cm}$ with a SD of $0.42 \mathrm{~cm}$, ranging between 0.1 and $2.0 \mathrm{~cm}$. The median value was $0.5 \mathrm{~cm}$. ITF size was divided into two groups: small was defined as $0.5 \mathrm{~cm}$ or less, large was defined as over $0.5 \mathrm{~cm}$. Large ITF size is associated with a higher Fuhrman nuclear grade $(\mathrm{p}=.007)$ (Table 5).

\section{Association between ITF and patient prognosis}

The 5-year overall survival rate of patients excluding loss to follow-up was 94.2\% (180/191). Patients without ITF had 100\% (36/36) 5-year overall survival rate, and patients with ITF had 92.9\% (144/155) 5-year overall survival rate. The p-value was .104 (Fig. 4). Statistically, ITF and 5-year overall survival rate showed no significant correlation.

Table 3. Associations of intratumoral inflammation with clinicopathologic characteristics

\begin{tabular}{|c|c|c|c|}
\hline \multirow{2}{*}{$\begin{array}{l}\text { Clinicopathological } \\
\text { parameters }\end{array}$} & \multicolumn{2}{|c|}{ Intratumoral inflammation } & \multirow{2}{*}{$p$-value } \\
\hline & Absent & Present & \\
\hline \multicolumn{4}{|l|}{ Age (yr) } \\
\hline$<60$ & $67(66.3)$ & $34(33.7)$ & .735 \\
\hline$\geq 60$ & $66(64.1)$ & 37 (35.9) & \\
\hline \multicolumn{4}{|l|}{ Sex } \\
\hline Male & $85(61.2)$ & $54(38.8)$ & .076 \\
\hline Female & $48(73.8)$ & $17(26.2)$ & \\
\hline \multicolumn{4}{|l|}{ Tumor size (cm) } \\
\hline$\leq 7$ & $120(71.4)$ & $48(28.6)$ & $<.001^{* * *}$ \\
\hline$>7$ & $13(36.1)$ & $23(63.9)$ & \\
\hline \multicolumn{4}{|l|}{ Fuhrman nuclear grade } \\
\hline Low (grade 1 and 2) & $102(78.5)$ & $28(21.5)$ & $<.001^{* * *}$ \\
\hline High (grade 3 and 4) & $31(41.9)$ & $43(58.1)$ & \\
\hline \multicolumn{4}{|l|}{ Pathologic stage } \\
\hline Low (stage 1 and 2) & $120(69.4)$ & $53(30.6)$ & $.004^{* *}$ \\
\hline High (stage 3 and 4) & $13(41.9)$ & $18(58.1)$ & \\
\hline \multicolumn{4}{|l|}{ Lymphovascular invasion } \\
\hline Absent & $124(70.9)$ & $51(29.1)$ & $<.001^{* * *}$ \\
\hline Present & $9(31.0)$ & $20(69.0)$ & \\
\hline \multicolumn{4}{|l|}{ Tumor necrosis } \\
\hline Absent & $124(73.4)$ & $45(26.6)$ & $<.001^{* * *}$ \\
\hline Present & $9(25.7)$ & $26(74.3)$ & \\
\hline \multicolumn{4}{|l|}{ Intratumoral fibrosis } \\
\hline Absent & $25(67.6)$ & $12(32.4)$ & .738 \\
\hline Present & $108(64.7)$ & 59 (35.3) & \\
\hline \multicolumn{4}{|l|}{ LOX expression } \\
\hline Absent & $60(64.5)$ & $33(35.5)$ & .852 \\
\hline Present & $73(65.8)$ & $38(34.8)$ & \\
\hline
\end{tabular}

Values are presented as number (\%).

LOX, lysyl oxidase.

${ }^{* *} \mathrm{p}<.01,{ }^{* * *} \mathrm{p}<.001$ 


\section{DISCUSSION}

There are many similar mechanisms between tumor development, tumor metastases, and formation of fibrosis. One of these mechanisms is ECM remodeling, ${ }^{17,18}$ which occurs predominantly while forming fibrosis and results in many changes in the ECM. These changes also activate other signaling pathways. ${ }^{10,11,19}$

Inflammatory cell infiltration in tumors and the tumor microenvironment is a significant factor in tumor progression. Recent studies have shown that tumor-associated immune cells play a role in RCC initiation and development. ${ }^{20,21}$ Some inflammatory cells in RCC, such as T lymphocytes and macrophages, may affect tumor progression and invasion. ${ }^{22}$ Yang $e t ~ a l .{ }^{23}$ reported that infiltrating macrophages could accelerate cancer invasion by increasing the epithelial to mesenchymal transition. This ability of macrophages is thought to be associated with activation of the AKT/mammalian target of rapamycin signal. Further research on this pathway could be helpful in developing a new target

Table 4. Associations of LOX expression with clinicopathologic characteristics

\begin{tabular}{|c|c|c|c|}
\hline \multirow{2}{*}{$\begin{array}{l}\text { Clinicopathological } \\
\text { parameter }\end{array}$} & \multicolumn{2}{|c|}{ LOX expression } & \multirow{2}{*}{$p$-value } \\
\hline & Absent & Present & \\
\hline \multicolumn{4}{|l|}{ Age (yr) } \\
\hline$<60$ & $43(42.6)$ & $58(57.4)$ & .392 \\
\hline$\geq 60$ & $50(48.5)$ & $53(51.5)$ & \\
\hline \multicolumn{4}{|l|}{ Sex } \\
\hline Male & $61(43.9)$ & $78(56.1)$ & .475 \\
\hline Female & $32(49.2)$ & $33(50.8)$ & \\
\hline \multicolumn{4}{|l|}{ Tumor size (cm) } \\
\hline$\leq 7$ & $77(45.8)$ & $91(54.2)$ & .879 \\
\hline$>7$ & $16(44.4)$ & $20(55.6)$ & \\
\hline \multicolumn{4}{|l|}{ Fuhrman nuclear grade } \\
\hline Low (grade 1 and 2) & $56(43.1)$ & $74(56.9)$ & .209 \\
\hline High (grade 3 and 4) & $37(50.0)$ & $37(50.0)$ & \\
\hline \multicolumn{4}{|l|}{ Pathologic stage } \\
\hline Low (stage 1 and 2) & $77(44.5)$ & $96(55.5)$ & .295 \\
\hline High (stage 3 and 4) & $16(51.6)$ & $15(48.4)$ & \\
\hline \multicolumn{4}{|l|}{ Lymphovascular invasion } \\
\hline Absent & $76(43.4)$ & $99(56.6)$ & .128 \\
\hline Present & $17(58.6)$ & $12(41.4)$ & \\
\hline \multicolumn{4}{|l|}{ Tumor necrosis } \\
\hline Absent & $80(47.3)$ & $89(52.7)$ & .270 \\
\hline Present & $13(37.1)$ & $22(62.9)$ & \\
\hline \multicolumn{4}{|l|}{ Intratumoral inflammation } \\
\hline Absent & $7(5.3)$ & $126(94.7)$ & .911 \\
\hline Present & $4(5.6)$ & $67(94.4)$ & \\
\hline \multicolumn{4}{|l|}{ Intratumoral fibrosis } \\
\hline Absent & $16(43.2)$ & $21(56.8)$ & .752 \\
\hline Present & $77(46.1)$ & $90(53.9)$ & \\
\hline
\end{tabular}

Values are presented as number (\%).

LOX, lysyl oxidase. therapy for RCC.

There is increasing evidence that ITF is associated with poor prognosis in breast cancers. ${ }^{15,16}$ ITF is related to many factors,

Table 5. Associations of intratumoral fibrosis size with clinicopathologic characteristics

\begin{tabular}{|c|c|c|c|}
\hline \multirow{2}{*}{$\begin{array}{l}\text { Clinicopathological } \\
\text { parameter }\end{array}$} & \multicolumn{2}{|c|}{ Intratumoral fibrosis size (cm) } & \multirow{2}{*}{$\mathrm{p}$-value } \\
\hline & $\leq 0.5$ & $>0.5$ & \\
\hline \multicolumn{4}{|l|}{ Age $(y r)$} \\
\hline$<60$ & $57(71.3)$ & $23(28.7)$ & .523 \\
\hline$\geq 60$ & $58(66.7)$ & $29(33.3)$ & \\
\hline \multicolumn{4}{|l|}{ Sex } \\
\hline Male & $82(72.6)$ & $31(27.4)$ & .135 \\
\hline Female & $33(61.1)$ & $21(38.9)$ & \\
\hline \multicolumn{4}{|l|}{ Tumor size (cm) } \\
\hline$\leq 7$ & 96 (71.6) & $38(28.4)$ & .118 \\
\hline$>7$ & $19(57.6)$ & $14(42.4)$ & \\
\hline \multicolumn{4}{|l|}{ Fuhrman nuclear grade } \\
\hline Low (grade 1 and 2) & 76 (76.8) & $23(23.2)$ & $.007^{* *}$ \\
\hline High (grade 3 and 4) & $39(57.4)$ & $29(42.6)$ & \\
\hline \multicolumn{4}{|l|}{ Pathologic stage } \\
\hline Low (stage 1 and 2) & $97(69.3)$ & $43(30.7)$ & .475 \\
\hline High (stage 3 and 4) & $18(66.7)$ & $9(33.3)$ & \\
\hline \multicolumn{4}{|l|}{ Lymphovascular invasion } \\
\hline Absent & $100(71.9)$ & $39(28.1)$ & .055 \\
\hline Present & $15(53.6)$ & $13(46.4)$ & \\
\hline \multicolumn{4}{|l|}{ Tumor necrosis } \\
\hline Absent & 95 (70.9) & $39(29.1)$ & .253 \\
\hline Present & $20(60.6)$ & $13(39.4)$ & \\
\hline \multicolumn{4}{|l|}{ Intratumoral inflammaion } \\
\hline Absent & 78 (72.2) & $30(27.8)$ & .205 \\
\hline Present & $37(62.7)$ & $22(37.3)$ & \\
\hline \multicolumn{4}{|l|}{ LOX expression } \\
\hline Absent & $50(64.9)$ & $27(35.1)$ & .311 \\
\hline Present & $65(72.2)$ & $25(27.8)$ & \\
\hline
\end{tabular}

Values are presented as number (\%).

LOX, lysyl oxidase.

${ }^{* *} \mathrm{p}<.01$

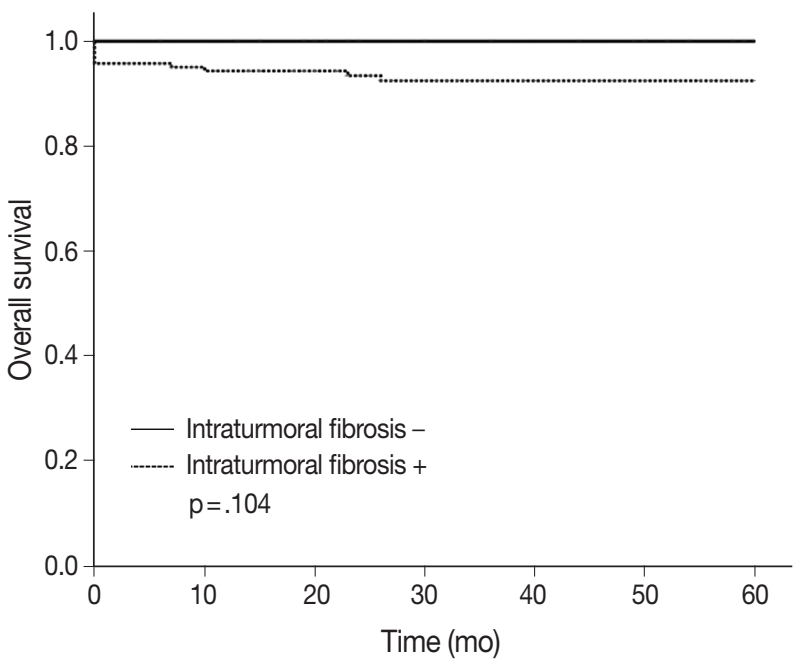

Fig. 4. 5-Year overall survival rate according to intratumoral fibrosis. 
such as higher histologic grade, pathologic T stage, lymph node metastasis, and increased risk of recurrence in breast cancer. In many studies, ITF as a prognostic factor independently correlates with other prognostic factors. ${ }^{24}$ In 1987, Delahunt and Nacey ${ }^{25}$ studied prognostic factors of RCC with 102 cases. They accessed many clinicopathological parameters to find any relationship with prognosis. They categorized fibrosis into three groups: slight or absent, moderate, and severe. Their study showed that fibrosis was not correlated with prognosis of RCC.

In our study, ITF is related to higher histologic grade, LVI, ITN, and ITI in CCRCC. Frank et al. ${ }^{26}$ reported that ITN is a prognostic factor according to the SSIGN (tumor stage, size, grade, and necrosis) scoring system. Our result shows that ITF and ITI are strongly associated with ITN. We statistically analyzed two groups of ITF to identify differences between the presence and grades of ITF. In group 1, ITF 0 was classified as negative, and ITF 1, 2, and 3 were classified as positive. In group 2, ITF 0 and 1 were considered negative, and ITF 2 and 3 were considered positive. Statistically, no significant differences were identified between these two groups, probably because the presence of ITF itself is a meaningful finding rather than ITF grade. The large ITF size is related to a higher Fuhrman nuclear grade. The 5-year overall survival rate tends to be better for patients who do not have ITF, but statistical significance has not been identified $(\mathrm{p}=$ $.104)$.

LOX modifies collagen and elastin fibers in the $\mathrm{ECM} \cdot{ }^{27}$ Collagen I is the most common substrate used by LOX. The most important factor in forming fibrosis is increased synthesis of ECM protein by fibroblast activation, and collagen type $I$ is the most commonly synthesized protein during this process. When collagen I is present at a high level in vital organs, it sometimes causes severe morbidity and mortality. Many studies have shown that collagen I plays a major role in cancer development and metastases. ${ }^{28}$ In breast cancers, the formation of fibrosis by remodeling of the ECM was also found to be associated with gene expression patterns related to adverse prognosis and cancer metastasis. ${ }^{29-32}$ Jensen et al. ${ }^{33}$ reported that, in recurrent breast cancer, an increased level of the collagen I precursor, procollagen I, could be detected in patient serum.

In this study, we investigated the relationship between LOX expression and ITF formation. Our hypothesis was that LOX participates in formation of ITF in CCRCC. However, our results show no correlation between LOX expression and ITF formation or other clinicopathologic features. Hence, ITF in CCRCC may be formed by other cytokines during ECM remodeling. Further study of other fibrogenic cytokines, such as transforming growth factor $\beta$ and tumor necrosis factor $\alpha$, is needed.

Our results show no relationship of ITF or ITI with LOX expression; there may be some reasons for this result. First, LOX is not involved in forming ITF of CCRCC. Second, there could be other classifications for grading LOX expression. We assumed that all normal tubular cells show no reactivity to LOX, although some normal tubular cells showed grade 1 expression. If we adjust LOX grading, different results may be obtained. We also found relatively low rates of death by CCRCC because the follow-up period was short and there was a high proportion of low-grade patients (Fuhrman nuclear grade 1 or 2).

Our results show that ITF is a pathologic finding related to other adverse prognostic factors, including higher Fuhrman nuclear grade, ITN, and LVI. However, ITF itself shows no direct correlation with poor prognosis of CCRCC. LOX expression shows no correlation with ITF or any other clinicopathologic parameters in this study. Further evaluation of other fibrogenic cytokines in addition to LOX should be considered.

\section{Conflicts of Interest}

No potential conflict of interest relevant to this article was reported.

\section{REFERENCES}

1. Siegel RL, Miller KD, Jemal A. Cancer statistics, 2016. CA Cancer J Clin 2016; 66: 7-30.

2. Joung JY, Lim J, Oh CM, et al. Current trends in the incidence and survival rate of urological cancers in Korea. Cancer Res Treat 2017; 49: 607-15.

3. Srigley JR, Delahunt B, Eble JN, et al. The International Society of Urological Pathology (ISUP) Vancouver classification of renal neoplasia. Am J Surg Pathol 2013; 37: 1469-89.

4. Gerlinger M, Rowan AJ, Horswell S, et al. Intratumor heterogeneity and branched evolution revealed by multiregion sequencing. $\mathrm{N}$ Engl J Med 2012; 366: 883-92.

5. Beksac AT, Paulucci DJ, Blum KA, Yadav SS, Sfakianos JP, Badani KK. Heterogeneity in renal cell carcinoma. Urol Oncol 2017; 35: 507-15.

6. Hiley C, de Bruin EC, McGranahan N, Swanton C. Deciphering intratumor heterogeneity and temporal acquisition of driver events to refine precision medicine. Genome Biol 2014; 15: 453.

7. Palsdottir HB, Hardarson S, Petursdottir V, et al. Incidental detection of renal cell carcinoma is an independent prognostic marker: results of a long-term, whole population study. J Urol 2012; 187: 48-53. 
8. Steeg PS. Tumor metastasis: mechanistic insights and clinical challenges. Nat Med 2006; 12: 895-904.

9. Cox TR, Bird D, Baker AM, et al. LOX-mediated collagen crosslinking is responsible for fibrosis-enhanced metastasis. Cancer Res 2013; 73: 1721-32.

10. Bissell MJ, Labarge MA. Context, tissue plasticity, and cancer: are tumor stem cells also regulated by the microenvironment? Cancer Cell 2005; 7: 17-23.

11. Paszek MJ, Zahir N, Johnson KR, et al. Tensional homeostasis and the malignant phenotype. Cancer Cell 2005; 8: 241-54.

12. Cox TR, Erler JT. Remodeling and homeostasis of the extracellular matrix: implications for fibrotic diseases and cancer. Dis Model Mech 2011; 4: 165-78.

13. Lucero HA, Kagan HM. Lysyl oxidase: an oxidative enzyme and effector of cell function. Cell Mol Life Sci 2006; 63: 2304-16.

14. Chang HM, Cheng JC, Liu Y, Klausen C, Xu C, Leung PC. Activin A-induced increase in LOX activity in human granulosa-lutein cells is mediated by CTGF. Reproduction 2016; 152: 293-301.

15. Mujtaba SS, Ni YB, Tsang JY, et al. Fibrotic focus in breast carcinomas: relationship with prognostic parameters and biomarkers. Ann Surg Oncol 2013; 20: 2842-9.

16. Hasebe T, Sasaki S, Imoto S, Mukai K, Yokose T, Ochiai A. Prognostic significance of fibrotic focus in invasive ductal carcinoma of the breast: a prospective observational study. Mod Pathol 2002; 15: 50216.

17. Wynn TA. Common and unique mechanisms regulate fibrosis in various fibroproliferative diseases. J Clin Invest 2007; 117: 524-9.

18. Keeley EC, Mehrad B, Strieter RM. Fibrocytes: bringing new insights into mechanisms of inflammation and fibrosis. Int J Biochem Cell Biol 2010; 42: 535-42.

19. Butcher DT, Alliston T, Weaver VM. A tense situation: forcing tumour progression. Nat Rev Cancer 2009; 9: 108-22.

20. Geissler K, Fornara P, Lautenschläger C, Holzhausen HJ, Seliger B, Riemann D. Immune signature of tumor infiltrating immune cells in renal cancer. Oncoimmunology 2015; 4: e985082.

21. Fang LY, Izumi K, Lai KP, et al. Infiltrating macrophages promote prostate tumorigenesis via modulating androgen receptor-mediated CCL4-STAT3 signaling. Cancer Res 2013; 73: 5633-46.

22. Minárik I, Laštovička J, Budinský V, et al. Regulatory T cells, dendrit- ic cells and neutrophils in patients with renal cell carcinoma. Immunol Lett 2013; 152: 144-50.

23. Yang Z, Xie H, He D, Li L. Infiltrating macrophages increase RCC epithelial mesenchymal transition (EMT) and stem cell-like populations via AKT and mTOR signaling. Oncotarget 2016; 7: 44478-91.

24. Hasebe T, Mukai K, Tsuda H, Ochiai A. New prognostic histological parameter of invasive ductal carcinoma of the breast: clinicopathological significance of fibrotic focus. Pathol Int 2000; 50: 263-72.

25. Delahunt B, Nacey JN. Renal cell carcinoma. II. Histological indicators of prognosis. Pathology 1987; 19: 258-63.

26. Frank I, Blute ML, Cheville JC, Lohse CM, Weaver AL, Zincke H. An outcome prediction model for patients with clear cell renal cell carcinoma treated with radical nephrectomy based on tumor stage, size, grade and necrosis: the SSIGN score. J Urol 2002; 168: 2395400.

27. Kagan HM, Li W. Lysyl oxidase: properties, specificity, and biological roles inside and outside of the cell. J Cell Biochem 2003; 88: 660-72.

28. Egeblad M, Rasch MG, Weaver VM. Dynamic interplay between the collagen scaffold and tumor evolution. Curr Opin Cell Biol 2010; 22: 697-706.

29. Ma XJ, Dahiya S, Richardson E, Erlander M, Sgroi DC. Gene expression profiling of the tumor microenvironment during breast cancer progression. Breast Cancer Res 2009; 11: R7.

30. Ramaswamy S, Ross KN, Lander ES, Golub TR. A molecular signature of metastasis in primary solid tumors. Nat Genet 2003; 33: 49-54.

31. Calvo A, Catena R, Noble MS, et al. Identification of VEGF-regulated genes associated with increased lung metastatic potential: functional involvement of tenascin-C in tumor growth and lung metastasis. Oncogene 2008; 27: 5373-84.

32. Qiu TH, Chandramouli GV, Hunter KW, Alkharouf NW, Green JE, Liu ET. Global expression profiling identifies signatures of tumor virulence in MMTV-PyMT-transgenic mice: correlation to human disease. Cancer Res 2004; 64: 5973-81.

33. Jensen BV, Johansen JS, Skovsgaard T, Brandt J, Teisner B. Extracellular matrix building marked by the $\mathrm{N}$-terminal propeptide of procollagen type I reflect aggressiveness of recurrent breast cancer. Int J Cancer 2002; 98: 582-9. 